\title{
Histomorphometric Analysis of Rat Alveolar Wound Healing with Hydroxyapatite Alone or Associated to BMPs
}

\author{
Alexandre C. BRANDÃO \\ Luís Guilherme BRENTEGANI \\ Arthur B. NOVAES Jr. \\ Márcio Fernando M. GRISI \\ Sérgio Luís Scombatti de SOUZA \\ Mario TABA Jr. \\ Luiz Antônio SALATA \\ Department of Bucco-Maxillo-Facial Surgery and Traumatology and Periodontology, \\ Faculty of Dentistry of Ribeirão Preto, University of São Paulo, Ribeirão Preto, SP, Brazil
}

\begin{abstract}
Several materials and techniques have been proposed to improve alveolar wound healing and decrease loss of bone height and thickness that normally follow dental extraction. The objective of this research was the histologic analysis of bone morphogenetic proteins implanted into dental alveoli of rats after extraction. A total of 45 adult male Wistar rats were divided into three groups of 15 animals each: control (no treatment), implanted with pure hydroxyapatite (HA, $3 \mathrm{mg}$ ) and implanted with hydroxyapatite plus bone morphogenetic proteins (HA/BMPs, $3 \mathrm{mg}$ ). Five animals from each group were sacrificed at 7, 21 and 42 days after extraction for the histometric analyses of the osteoconductive potential of hydroxyapatite associated or not with BMPs. After dissection, fixation, decalcification and serial microtomy of $6-\mu \mathrm{m}$ thick sections, the samples were stained with hematoxylin-eosin for histologic and histometric analyses. Both HA and HA/BMPs caused a delay in wound healing compared to control animals, evaluated by the percentage of bone tissue in the alveoli. The treatment with HA/BMPs had the greatest delay at 21 days, even though it produced values similar to the control group at 42 days. The materials did not improve alveolar repair in the normal period of wound healing and the association of HA/BMPs did not have osteoconductive properties with granulated hydroxyapatite as the vehicle.
\end{abstract}

Key words: alveolar wound healing, hydroxyapatite, BMPs.

\section{INTRODUCTION}

Alveolar ridge maintenance after dental extraction is a problem that still concerns those involved with rehabilitation of masticatory function. Many techniques and materials have been tested in the last decades for the purpose of avoiding or delaying alveolar bone resorption resulting from extraction. However, none have proven to be completely effective.

The chronology and characteristics of alveolar wound healing have been extensively investigated $(1,2)$ and recently this model was used to analyze and compare several materials for the maintenance of local bone volume. The use of materials to improve bone neofor- mation in alveoli immediately following dental extraction seems to delay the repair process. This was reported with the use of microgranular hydroxyapatite (HA), tricalcium phosphate, Riccinus comunis and glass ionomer, which had little or no effect when compared to control groups (3). On the other hand, clinical studies showed that tricalcium phosphate bioceramics, as well as bioactive glass, can contribute to the maintenance of the alveolar ridge (4). Despite clinical limitations offering conditions for adequate histological analysis, the results with osteoconductive materials - especially those related to HA and tricalcium phosphate - seem very encouraging (5).

Since Urist (6) observed that proteins naturally 
found in osseous organic matrix, named bone morphogenetic proteins (BMPs), were capable of inducing bone neoformation, studies were intensified to test the clinical applicability of recombining forms of this material. BMPs are natural glycoproteins with low molecular weight, osteoinductive, capable of suppressing mitosis and intensifying mesenchymal cell differentiation into condroblasts and osteoblasts. Currently, fifteen amino acid sequences are known, with the most active in humans being BMP-2, BMP-4, and BMP-7 (7). Even though there is no doubt about the advantages of BMPs in bone neoformation $(8,9)$, recent studies are directed to techniques that allow BMPs release in adequate concentrations to encourage bone neoformation, which seems to be related to the physical and chemical properties of the vehicle. In spite of the tendency to use the collagen sponge as a vehicle (10), other vehicles deserve more study. BMPs can be taken to implantation sites through bone organic matrix or associated with osteoconductive materials.

Yoshida et al. (11) reported that the association of porous HA with rhBMP was more effective in mandible defects of rabbits rather than HA alone. Itoh et al. (12) analyzed HA and a collagen compound for biocompatibility, osteoconductibility and efficiency as an rhBMP-2 carrier applied to bone defects produced in dog radius and ulna. The combination was biocompatible and abbreviated callus formation and bone union. Comparative studies of ceramic materials with different proportions of HA and tricalcium phosphate with different doses of rhBMP-2 in rat calvaria (13) showed that $25 \% \mathrm{HA} / 75 \%$ tricalcium phosphate was related to the lowest number of remanescent particles eight weeks after implantation, indicating that ceramic absorption produced favorable conditions for bone formation induced by BMPs. Therefore, there is evidence that the combination of an osteoinductive material (BMPs) with an osteoconductive one (HA) results in a synergic effect for bone neoformation, even though the ideal concentration of BMPs that must be absorbed is still unknown.

In the present investigation, the osteoinductive material used was a pool of BMPs (BMP-2, BMP-3, BMP-4 and BMP-7) extracted from bovine fetal bone organic matrix and absorbed HA in the proportion of 1:20. The use of absorbable HA as the carrier allows these proteins to remain available longer in the surgical cavity, avoiding fast degradation. In the majority of studies of the association of BMPs and HA, the osteoinductive material was rhBMP-2. Considering that bone formation is the result of an intricate system of factors, it is reasonable to believe that this process would be favored by the addition of a pool of BMPs. The purpose of the present investigation was to evaluate, histometrically, the effect of the association of a pool of BMPs with absorbable granulated hydroxyapatite, when applied in rat alveoli immediately following dental extraction.

\section{MATERIAL AND METHODS}

A total of 45 adult male Wistar rats (150-200 g body weight), supplied by the Central Biotery (USP, Ribeirão Preto, SP) were housed in cages under controlled lighting (lights on from 6:00 to 18:00) and environmental temperature $\left(23.2^{\circ} \mathrm{C}\right)$. Laboratory chow and tap water were given ad libitum.

The animals were anesthetized with an intraperitoneal injection of $10 \%$ chloral hydrate $(0.4 \mathrm{ml} / 100 \mathrm{~g}$ body weight). The upper right incisor was extracted with an adapted forceps after separation of the surrounding gingiva. The animals were divided into 3 groups of 15 animals each: control (no treatment), alveolus implanted with pure hydroxyapatite (HA, 3 mg; Baumer Ortopedia S/A, Mogi Mirim, SP, Brazil), and alveolus implanted with hydroxyapatite plus bone morphogenetic proteins (HA/BMPs, $3 \mathrm{mg}$; Baumer Ortopedia S/A), with the aid of an amalgam holder adapted for this purpose. The porosity of both experimental materials was $5 \mu$ and the granulometry was 2.510. HA was non-resorbable and HA/BMPs was resorbable. The wounds were sutured with nylon wire (Mononylon 5-0, Ethicon, São José dos Campos, SP, Brazil) and a single intramuscular dose of antibiotic (Pentabiótico Veterinário, Fontoura-Wyeth, Campinas, SP, Brazil) was administered. Each animal was observed daily to record any post-surgical complication.

Five animals from each group were sacrificed by ether inhalation 7, 21 and 42 days after dental extraction. The right maxilla was separated from the left maxilla and the samples were fixed in $10 \%$ formalin, decalcified in a solution of $20 \%$ sodium citrate and $50 \%$ formic acid, dehydrated in different alcohol concentrations, cleared and embedded in paraffin. Longitudinal $6-\mu \mathrm{m}$ thick sections were cut at $60 \mu \mathrm{m}$ intervals. Histologic and histometric analyses were performed after 
staining with hematoxylin and eosin.

The local response to material implantation, identification of cell type and wound healing were evaluated with the light microscope.

Volume fraction of healing alveolar components was estimated by a differential point-counting method, with the histologic images analyzed with an integration eyepiece with 100 equidistant points fitted to a light microscope (final magnification 40X). One thousand points per alveoli (corresponding to the product of 10 microscopic fields by 100 points from the eyepiece) were counted at 7,21 and 42 days after dental extraction. The percentage of points was distributed by connective tissue, bone trabeculae and material being proportional to their volume density.

The results were analyzed statistically by the non-parametric Mann-Whitney test (two by two) (GMC Basic Software, 7.3)

\section{RESULTS}

\section{Histologic Analysis}

7 days. In the alveoli of the control group, the connective tissue was rich in fibroblasts and capillaries, with few lymphocytes. The alveoli were partially filled by delicate immature bone trabeculae lined with osteoblasts (Figure 1, top). The rats treated only with HA showed granulation tissue with fibroblasts and neoformed capillaries around material granules and less immature bone tissue compared to the control group (Figure 1, middle). The animals that received HA/ BMPs showed no bone neoformation adjacent to the material, but there was a large amount of connective tissue with fibroblasts around material granules, and an intense inflammatory infiltrate composed mainly of lymphocytes (Figure 1, bottom).

21 days. Control alveoli were filled by wellorganized bone trabeculae and surrounded by osteoblasts (Figure 2, top). The alveoli implanted only with HA showed a connective tissue rich in fibroblasts and less neoformed capillaries and bone than the control. In some areas, the material was surrounded by bone (Figure 2, middle). In the group treated with HA/BMPs, there was a small quantity of neoformed immature bone and a large amount of connective tissue rich in fibroblasts lined with material granules (Figure 2, bottom). It was still possible to observe coagulum remnants in organization.

42 days. The alveolar cavity of the control group was filled with thick and mature bone trabeculae surrounded by medullar spaces filled by loose connective tissue. (Figure 3, top). In the group implanted with HA, the mature trabeculae were smaller than those of the control group, surrounded by material granules and
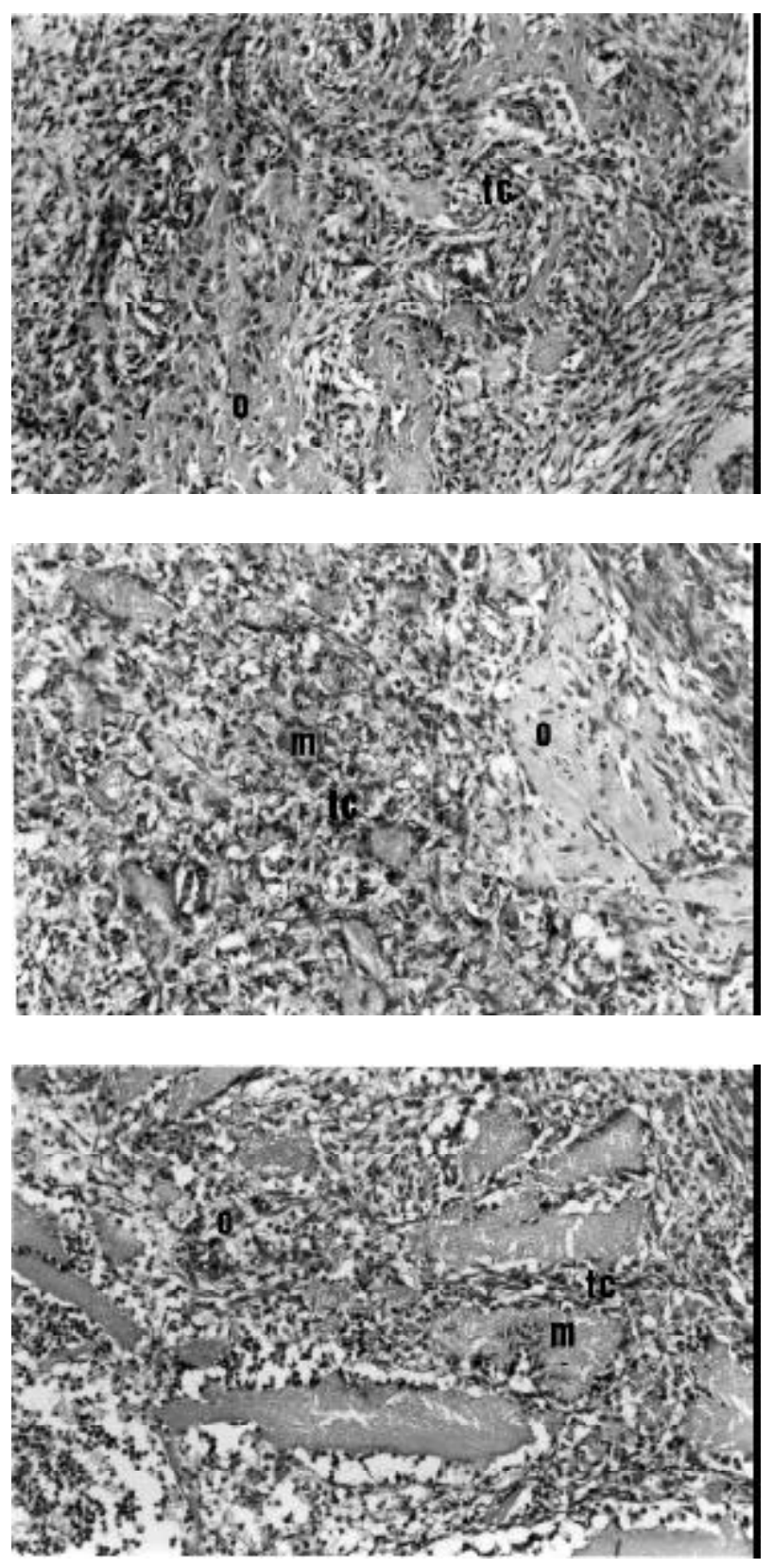

Figure 1. Histologic section of rat alveoli 7 days after dental extraction of the control group (top), HA group (middle) and HA/BMPs group (bottom). 0 - bone; tc - connective tissue; $\mathrm{m}$ material. Hematoxylin \& eosin; magnification 56X. 
little connective tissue and neoformed capillaries (Figure 3, middle). Animals treated with HA/BMPs had less bone trabeculae than animals implanted only with HA and the control group. Material granules were sometimes surrounded by bone and sometimes by connective tissue. There was still inflammatory infiltrate (Figure 3 , bottom).
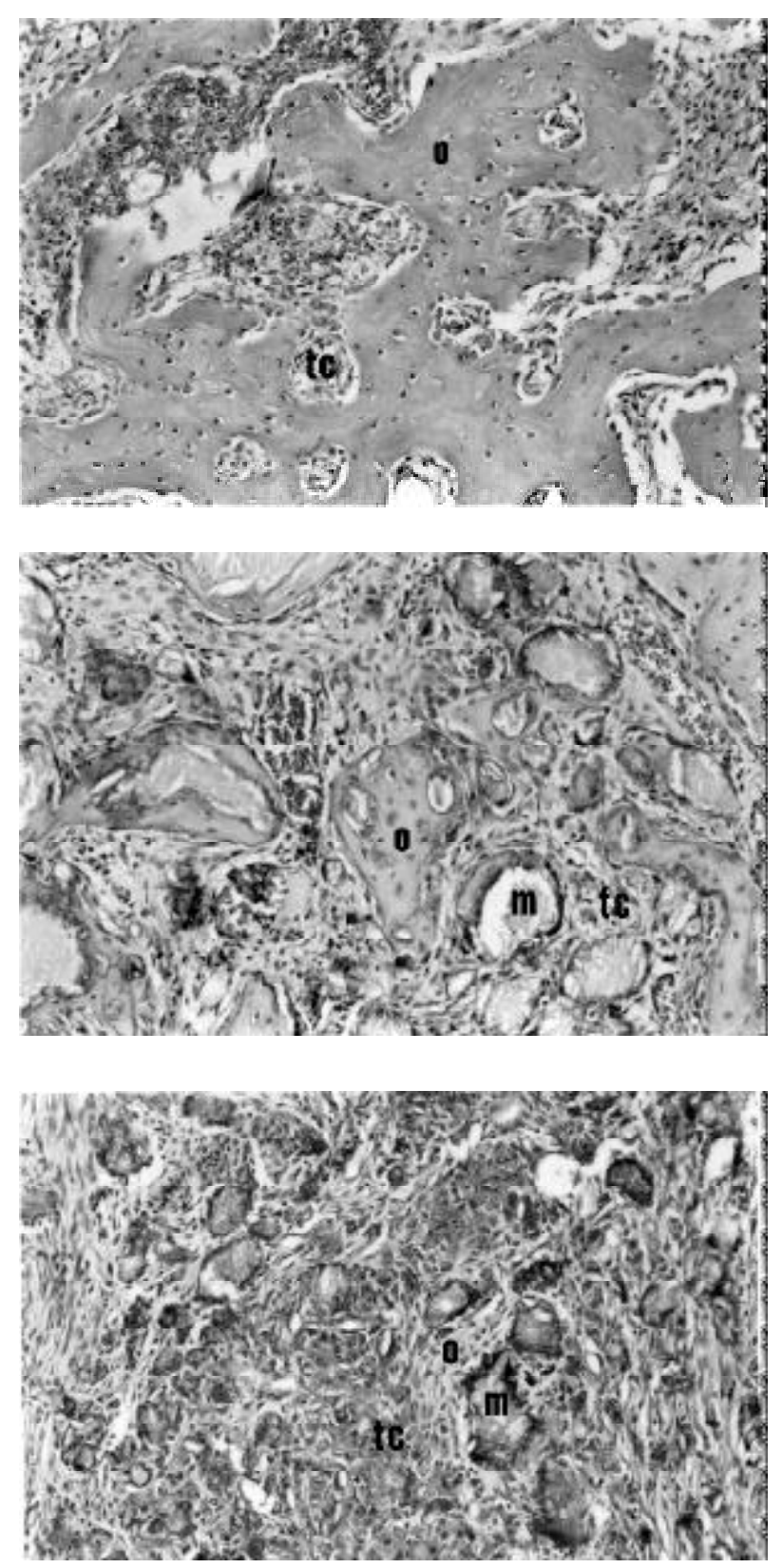

Figure 2. Histologic section of rat alveoli 21 days after dental extraction of the control group (top), HA group (middle) and HA/BMPs group (bottom). 0 - bone; tc - connective tissue; $\mathrm{m}$ material. Hematoxylin \& eosin; magnification 56X.

\section{Histometric Analysis}

Bone. In the three groups, bone tissue increased progressively from 7 to 42 days after extraction (Figure 4). On day 7, bone tissue volumes of control, HA and HA/BMPs groups were $25.0 \pm 0.9,25.6 \pm 1.2$ and 22.9 \pm 1.6 , respectively, with no statistical difference among
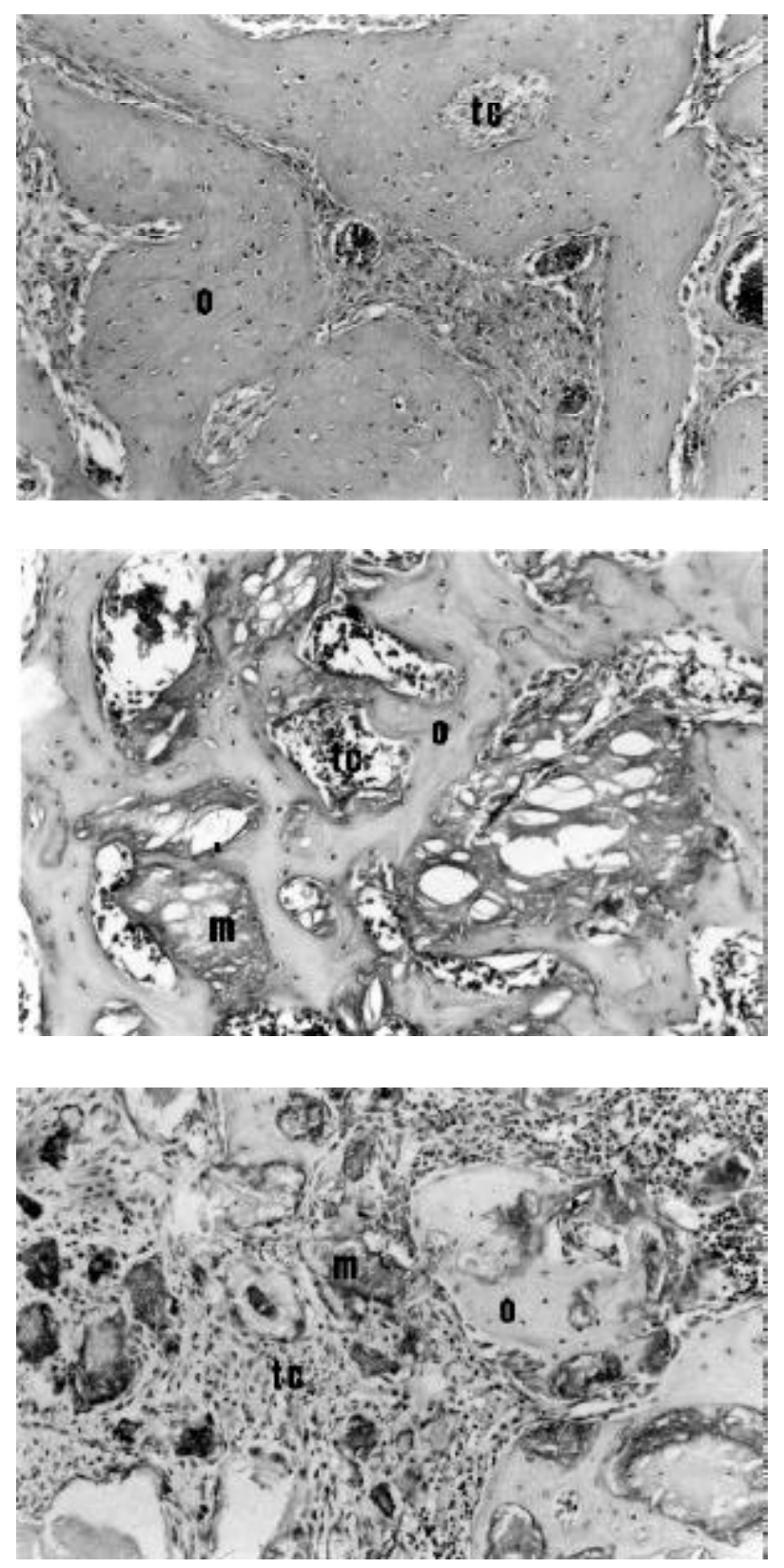

Figure 3. Histological section of rat alveoli 42 days after dental extraction of the control group (top), HA group (middle) and HA/BMPs group (bottom). 0 - bone; tc - connective tissue; $\mathrm{m}$ material. Hematoxylin \& eosin; magnification 56X. 
them. After 21 days, bone tissue volumes were $52.2 \pm$ $1.7,37.4 \pm 1.6$ and $28.9 \pm 2.9$, respectively. There was a statistical difference of $5 \%$ between HA and HA/ BMPs groups. Between control and both HA and HA/ BMPs groups, a statistical difference of $1 \%$ was found. After 42 days, bone tissue volumes were $69.3 \pm 1.9$, $57.2 \pm 3.6$, and $60.2 \pm 4.0$, respectively. There was no statistical difference between HA and HA/BMPs groups and HA/BMPs and control groups, however there was a statistical difference of $1 \%$ between HA and control groups.

Connective tissue. On day 7, connective tissue volumes of control, HA and HA/BMPs groups were $74.9 \pm 0.9,73.3 \pm 1.2$ and $75.6 \pm 1.9$, respectively, with no statistical difference among them. After 21 days, connective tissue volumes were $47.7 \pm 1.7,59.3 \pm 1.5$ and $67.5 \pm 3.0$, respectively. A significance of $5 \%$ was found between HA and HA/BMPs groups, whereas $1 \%$ was found between HA and control and HA/BMPs and control. After 42 days, connective tissue volumes were $30.6 \pm 1.9,41.3 \pm 3.9$, and $37.9 \pm 3.8$, respectively. There was a statistical difference between HA and control group of 5\%; however, there was no statistical difference between HA and HA/BMPs and HA/BMPs and control groups (Figure 4).

\section{DISCUSSION}

Wound healing is a sequence of cellular and tissues changes that occur inside the alveolus after dental extraction. Shortly after tooth extraction, the socket is filled with blood coagulum formed by blood vessel breakage from the periodontal ligament and apical foramen. There are four morphologic phases in the process of alveolar repair $(2,14)$. The first phase refers to cellular proliferation and infiltration of the coagulum by fibroblasts from the periodontal ligament. In the second phase, fibroblasts synthesize large amounts of fibers and amorphous substance. In the third phase, there is connective tissue maturation, characterized mainly by a decrease of cells and blood vessels and an increase of mature collagen fibers. The fourth phase is the progressive increase in the number and thickness of collagen fibers and a greater decrease in the number of fibroblasts and blood vessels. In this phase, osteoblast differentiation occurs, which initiates organic matrix synthesis that suffers progressive mineralization giving rise to bone trabeculae. In rats, alveolar repair is com- plete three weeks after dental extraction (3). In the present investigation, control values were similar to those found in the literature. The filling of the alveoli by well organized bone trabeculae lined by osteoblasts occurred 21 days after dental extraction. After 42 days, an increase of thick and mature bone trabeculae surrounded by small medullar spaces filled by loose connective tissue was observed.

Several alloplastic materials have been used in
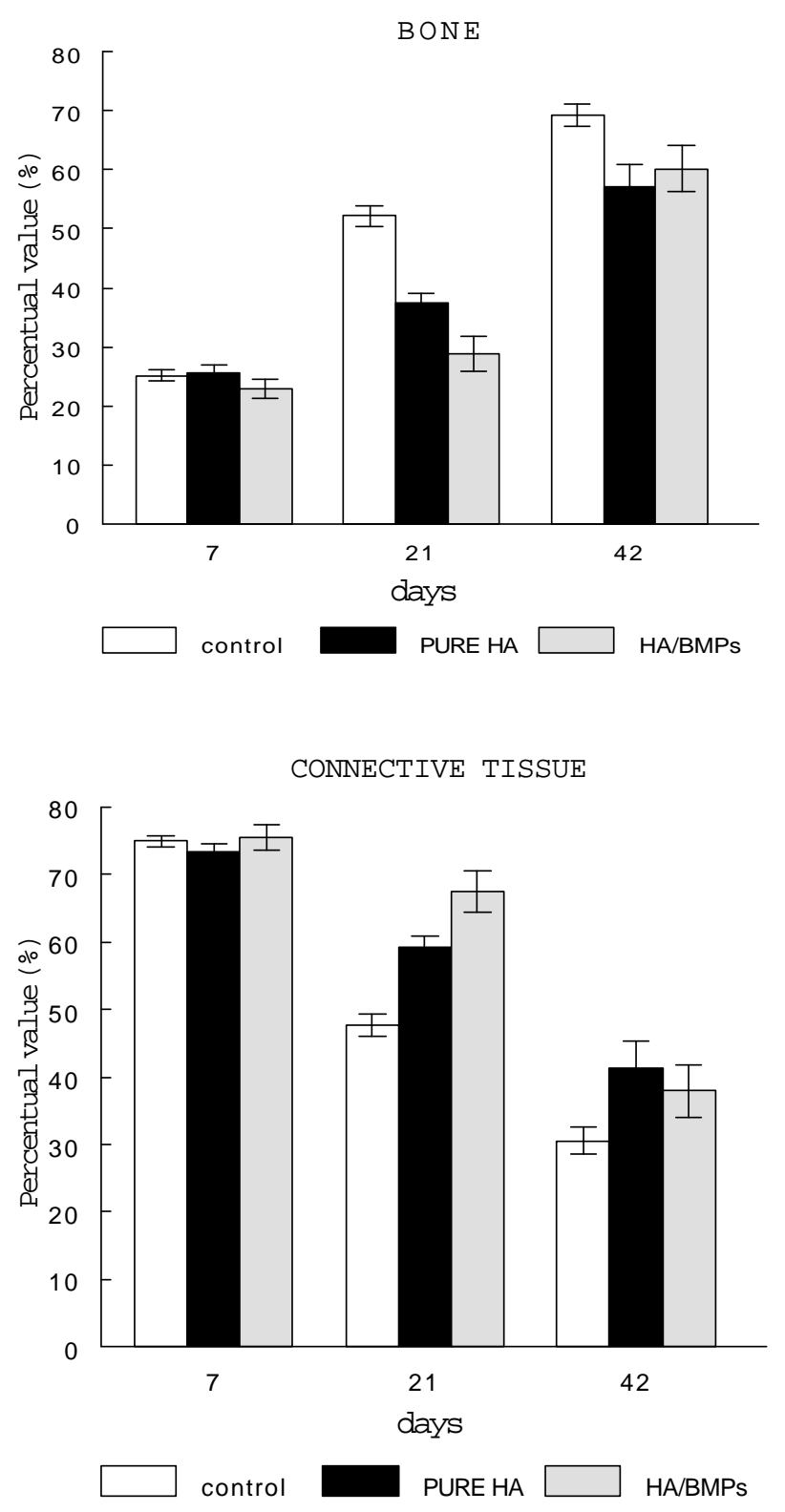

Figure 4. Percent of bone and connective tissue in rat alveoli of control, HA and HA/BMPs groups 7, 21 and 42 days after dental extraction. Mann-Whitney statistical test. 
surgery of intra-osseous defects as an alternative to autogenous grafts. HA and tricalcium phosphate are the most frequently used materials, mainly because of biocompatibility, bioactivity and osteoconduction properties $(15,16)$.

In the present study, alveoli implanted with HA showed a decrease in bone volume compared to the control group $(p \leq 0.01) 21$ and 42 days after dental extraction. These data reflect a significant delay in the chronology of alveolar repair, because even though there was a progressive increase in bone volume percentage over time, the presence of HA delayed the process of osseous deposit until the end of the experiment. These results are in agreement with previous studies which investigated HA implantation in rat alveoli (17), suggesting that this test model of alveolar repair is impaired by the presence of biocompatible materials such as HA. However, the persistence of HA particles in the alveoli and the absence of inflammation at 42 days indicates that implanted alveoli could be benefitted by the presence of the material over a longer time. Artzi et al. (4) implanted hydroxyapatite in dental extraction sites in humans and observed that bone filled $82.3 \%$ of the alveoli nine months after extraction. Therefore, the effects of particled HA longterm implantation in alveoli could result in the maintenance of its original dimensions, whereas control alveoli could be more severely affected by the osseous remodelation process.

Analysis of bone volume present at 21 days revealed significantly smaller values for the group treated with HA/BMPs compared to HA and control groups ( $\mathrm{p} \leq 0.01$ and $\mathrm{p} \leq 0.05$, respectively). After 42 days, however, bone formation in the HA/BMPs group was greater than the HA group, but without statistical significance. Although there are no similar studies showing BMPs behavior in rat dental extraction sites, the experimental model of alveolar repair used in this study is widely used and no other granular material is more effective in the repair process than the coagulum that occurs naturally after extraction. However, it was expected that the association of HA/BMPs would produce better results than the HA group at all time periods, which did not occur. Histologic analysis of the HA/BMPs group showed a large amount of loose connective tissue involving granules of the material and an intense inflammatory infiltrate at 7 days. The subsequent periods showed a small quantity of bone formation and abun- dance of connective tissue rich in fibroblasts involving particles of the material.

Three factors could be related to the poor results obtained with HA/BMPs: a) characteristics of experimental model, b) carrier properties and c) BMPs concentration. It is well known that BMPs promotes differentiation of mesenchymal and medullar cells into condroblasts (endochondral ossification) resulting in intermediate formation of cartilage, or into osteoblasts (intramembranous ossification) which leads to direct bone formation (18). It is accepted that the process of alveolar repair is initiated with the proliferation and differentiation of fibroblasts in osteoblasts and that the differentiation process could be mediated by receptors $\alpha$ - and $\beta$ - PDGF (14) originating from blood platelets. Thus, even though it seems reasonable to admit that the alveolar repair process is multi-mediated, it could be speculated that the use of BMPs would not be a limiting factor in this experimental model and therefore, the addition of BMPs would not result in a synergic effect on the production of osteoblasts.

Besides uncontestable osteoconductive capacity of BMPs, the expectancy of osseous regeneration as a consequence of its use is not always confirmed and the results may not be better than conventional treatment or even controls (19). These findings can be explained by the chronology in which different factors involved in osseous formation are needed, as well as the demand of each one in different tissues (20). Thus, different from bone defects in which medullar exposition and periosteal contact act as a source of mesenchymal cells (21), which are BMPs targets, the dental alveolus is an extremely differentiated system, and periodontal ligament breakage is the only injury produced during dental extraction. This could partially explain the discrepancy between the positive results observed previously with the association of BMP-2/HA in bone defects created in rabbit mandibles (11) and the ones obtained in the present study.

On the other hand, the carrier seems to have an important role in BMPs effectiveness. The understanding of the relationship between BMPs and the implantation vehicle properties has recently led to a search for intelligent carriers that would promote the release of osteoinductive substances when needed for bone formation (22). Recently, it was reported that collagen possesses better properties for this goal $(10,23)$. Even with BMP-2/HA applied successfully in the regenera- 
tion of mandibular bone defect, the carrier was collagen (11) with HA being the osteoconductive material. There are no studies proving that absorbable HA would favor BMPs release in the required time and concentration. Thus, the progressive release of BMPs from HA requires additional investigation, because of the need to conciliate factors such as protein incorporation to material, material absorption rate in the tissues, protein reconstruction rate at the site and the demand for BMPs. On the other hand, HA resorbable granules used as the vehicle for BMPs were associated with a more intense inflammatory infiltrate compared to sites treated with non-resorbable HA and without BMPs, mainly after 21 days. If this process was responsible for the unexpected results observed with the HA/BMPs association was not clear, because percent of bone tissue 42 days after implantation did not show any significant difference when compared to the control group. To establish if BMPs preserves alveolar ridge over the long-term with this model, further investigation using longer periods of time would be necessary.

\section{RESUMO}

Brandão AC, Brentegani LG, Novaes Jr AB, Grisi MFM, de Souza SLS, Taba Jr M, Salata LA. Análise histomorfométrica do processo de reparo alveolar após enxerto de hidroxiapatita pura e acrescida de BMPs em feridas de extração dental em ratos. Braz Dent J 2002;13(3):147-154.

Diferentes materiais e técnicas têm sido propostos com o objetivo de otimizar o reparo alveolar e atenuar a perda óssea em altura e espessura que normalmente seguem as extrações dentais. $\mathrm{O}$ objetivo era de estudar, por meio de análise histológica e histométrica, o potencial osseoindutivo de uma combinação de hidroxiapatita com proteínas óssea morfogenéticas (HA/BMPs) implantadas em alvéolos dentais de ratos. Foram utilizados 45 ratos Wistar, adultos, machos, separados em três grupos de 15 animais: controle (não-tratados), implantados com hidroxiapatita pura (HA) e implantados com hidroxiapatita acrescida com BMPs. Cinco animais de cada grupo foram sacrificados nos períodos de 7, 21 e 42 dias após a exodontia e implantação do material. Após dissecação, fixação, descalcificação e secções semi-seriadas as peças foram coradas pelo método de hematoxilina-eosina e submetidas à análise histológica e histométrica. Os materiais implantados produziram atraso na cronologia do reparo alveolar em comparação aos animais controle, avaliado pela porcentagem de tecido ósseo formado nos alvéolos. O tratamento com HA/BMPs esteve associado com a menor porcentagem de formação óssea no período de 21 dias, embora tenha produzido níveis próximos do controle aos 42 dias. Os materiais parecem não trazer benefícios à formação óssea no período normal de reparação alveolar e a associação HA/BMPs não apresentou propriedades osseoindutoras nas condições em que foi enxertada ou tendo como veículo a hidroxiapatita em formato granular.

Unitermos: reparo alveolar, hidroxiapatita, BMP.

\section{REFERENCES}

1. Amler M. The time sequence of tissue regeneration in human extraction sites. Oral Surg Oral Med Oral Pathol 1969;27:309318.

2. Lamano Carvalho T, Bombonato K, Brentegani L. Histometric analysis of rat alveolar wound healing. Braz Dent J 1997;8:9-12.

3. Lamano Carvalho T, Teófilo J, Araújo C, Brentegani L. Histologic and histometric evaluation of rat alveolar wound healing around polyurethane resin implants. Int J Oral Maxillofac Surg 1997;26:149-152.

4. Artzi Z, Tal H, Dayan D. Porous bovine bone mineral in healing of human extraction sockets. Part 1: Histomorphometric evaluations at 9 months. J Peridontol 2000;71:1015-1023.

5. Stephan E. Anorganic bovine bone supports osteoblastic cell attachment and proliferation. J Periodontol 1999;70:364-369.

6. Urist M. Bone formation by autoinduction. Science 1995; 150:893-899.

7. Rosen V, Cox K, Hattersley G. Bone morphogenetic proteins. In: Principles of bone biology. Bilezikian JP, Raisz LG, Rodan GA. Ed. San Diego: Academic Press Inc.; 1996. p 661-672.

8. Zellin G, Linde A. Importance of delivery systems for growthstimulatory factors in combination with osteopromotive membranes. An experimental study using rhBMP-2 in rat mandibular defects. J Biom Mater Res 1997;35:181-190.

9. Cochran D, Schenk R, Buser D, Wozney J, Jones A. Recombinant human bone morphogenetic protein-2 stimulation of bone formation around endosseous dental implants. J Periodontol 1999;70:139-150.

10. Boyne PJ. Animal studies of application of rhBMP-2 in maxillofacial reconstruction. Bone 1997;19(suppl):83S-92S.

11. Yoshida K, Bessho K, Fujimura K, Konishi Y, Kusumoto K, Ogawa Y, Iizuka T. Enhancement by recombinant human bone morphogenetic protein- 2 of bone formation by means of porous hydroxyapatite in mandibular bone defects. J Dent Res 1999;78:1505-1510.

12. Itoh S, Kikuchi M, Takakuda K, Koyama Y, Matsumoto H, Ichinose S, Tanaka J, Kawauchi T, Shinomiya K. The biocompatibility and osteoconductive activity of a novel hydroxyapatite/ collagen composite biomaterial and its function as a carrier of rhBMP-2. J Biomed Mater Res 2001;54:445-453.

13. Alam I, Asahina I, Ohmamiuda K, Enomoto S. Comparative study of biphasic calcium phosphate ceramics impregnated with rhBMP-2 as bone substitutes. J Biomed Mater Res 2001;54:129138.

14. Matsuda N, Lin W, Kumar N, Cho M, Genco R. Mitogenic, chemotactic, and synthetic responses of rat periodontal ligament fibroblastic cells to polypeptide growth factors in vitro. J Periodontol 1992;63:515-525.

15. Bagambisa F, Joos U. Preliminary studies on the phenomenological behavior of osteoblasts cultured on hydroxyapatite ceramics. Biomaterials 1990;11:50-56.

16. LeGeros R. Biodegradation and bioresorption of calcium phosphate ceramics. Clin Mater 1993;14:65-88.

17. Perri de Carvalho P, Garcia Jr I, Sanches M. Estudo comparativo entre as hidroxiapatitas: Osteosynt e HA-40. Rev Gaúcha Odont 1994;41:330-332. 
18. Wozney J. The potential role of bone morphogenetic proteins in periodontal reconstruction. J Periodontol 1995;66:506-510.

19. Sigurdsson T, Fu E, Tatakis D, Rohrer M. Bone morphogenetic protein-2 for peri-implant bone regeneration and osseointegration. Clin Oral Impl Res 1997;8:367-374.

20. Terheyden H, Jepsen S, Vogeler S, Tucker M, Rueger D. Recombinant human osteogenic protein 1 in the rat mandibular augmentation model: differences in morphology of the newly formed bone are dependent on the type of carrier. Mund Kiefer Gesichtschir 1997;41:112-114.

21. Kusumoto K, Bessho K, Fujimura K, Konishi Y, Ogawa Y, Yizuka T. Self-regenerating bone implant ectopic osteoinduction following intramuscular implantation of a combination of rhBMP2, atelopeptide type I collagen and porous hydroxyapatite. J Craniomaxillofac Surg 1996;24:360-365.

22. Ripamonti U, Crooks J, Ruegger D. Induction of bone formation by recombinant human osteogenic protein- 1 and sintered porous hydroxyapatite in adult primates. Plast Reconstr Surg 2001;107:977-988.

23. Uludag H, Gao T, Porter T, Friess W, Wozney J. Delivery systems for BMPs: factors contributing to protein retention at an application site. J Bone Joint Surg Am 2001;83-A (suppl 1, pt 2):S128S135.

Accepted March 27, 2002 